\title{
$\alpha$ Fetoprotein producing early gastric cancer with liver metastasis: report of three cases
}

\author{
Y-C Chang, N Nagasue, S Abe, H Kohno, D D Kumar, T Nakamura
}

\begin{abstract}
Three cases of $\alpha$ fetoprotein producing early gastric cancer are presented. Liver metastases occurred in all patients shortly after curative gastrectomy and all died within two years. The incidence of liver metastasis was significantly higher than that in $\alpha$ fetoprotein negative early gastric carcinoma $(p<0.001)$. The incidences of lymph node metastasis and invasion in lymph vessels and veins were also substantially higher in this group of patients. Two radical hepatic resections, including extended right lobectomy, were performed on one patient but the tumour recurred immediately.
\end{abstract}

$\alpha$ Fetoprotein, which is a normal product of fetal liver and yolk sac, was thought initially to be a specific tumour marker of primary hepatocellular carcinoma and embryonal cell carcinoma. With the advent of a more sensitive radioimmunoassay, $\alpha$ fetoprotein was frequently discovered in tumours of the gastrointestinal tract. ${ }^{1}$ Leader and Jass suggested that $\alpha$ fetoprotein production is linked with foregut neoplasia. ${ }^{2}$

$\alpha$ Fetoprotein producing gastric cancer was first reported in $1970 .^{3}$ Since then a few case reports have been published. The incidence was reported to be $3.9 \%$ to $15 \% .{ }^{14}$ Borrmann II and III types of gastric cancer were predominant. A high incidence of liver metastasis and poor prognosis were the characteristic clinical features. ${ }^{48}$ The incidence of liver metastasis was reported to be as high as $73 \cdot 7 \%{ }^{9}$ in a nationwide investigation in Japan.

Up to date reports of $\alpha$ fetoprotein producing early gastric cancer are scarce ${ }^{8}$ and little is known about the clinicopathological features. Whether it has as good a prognosis as early gastric cancer usually does ${ }^{10-14}$ is a matter of interest. Therefore, we report three cases with liver metastasis.

Second Department of

Surgery, Shimane

Medical University,

Izumo 693, Japan

Y-C Chang

N Nagasue

$S$ Abe

H Kohno

D D Kumar

T Nakamura

Correspondence to:

Dr Yu-Chung Chang.

Accepted for publication

3 July 1990

\section{Methods}

Since 1979 we have treated 162 cases of early gastric cancer. Among these, three were $\alpha$ fetoprotein producing cancer. The diagnosis was suspected by a raised serum $\alpha$ fetoprotein concentration and confirmed by positive $\alpha$ fetoprotein staining of the resected gastric and hepatic tumour specimens. Immunohistochemical staining was performed on all cases of early gastric cancer by the peroxidaseantiperoxidase method, with formalin fixed, paraffin embedded materials. The Dako Pap Kit (Dako, California, USA) was used.

Serum carcinoembryonic antigen and $\alpha$ fetoprotein concentrations were estimated by radioimmunoassay methods. Normal values were below $5 \mathrm{ng} / \mathrm{ml}$ and $20 \mathrm{ng} / \mathrm{ml}$, respectively.

\section{Case 1}

A 62 year old woman had complained of pain in the epigastrium of one month's duration. An upper gastrointestinal series and endoscopy of the stomach showed a IIa type adenocarcinoma at the gastric angle. On admission the serum $\alpha$ fetoprotein concentration was $146 \mathrm{ng} / \mathrm{ml}$.

Partial gastrectomy with $\mathbf{R}_{3}{ }^{15}$ lymph node dissection was performed. Randomised adjuvant chemotherapy for gastric cancer with mitomycin C $20 \mathrm{mg}$ and $10 \mathrm{mg}$ was given intravenously

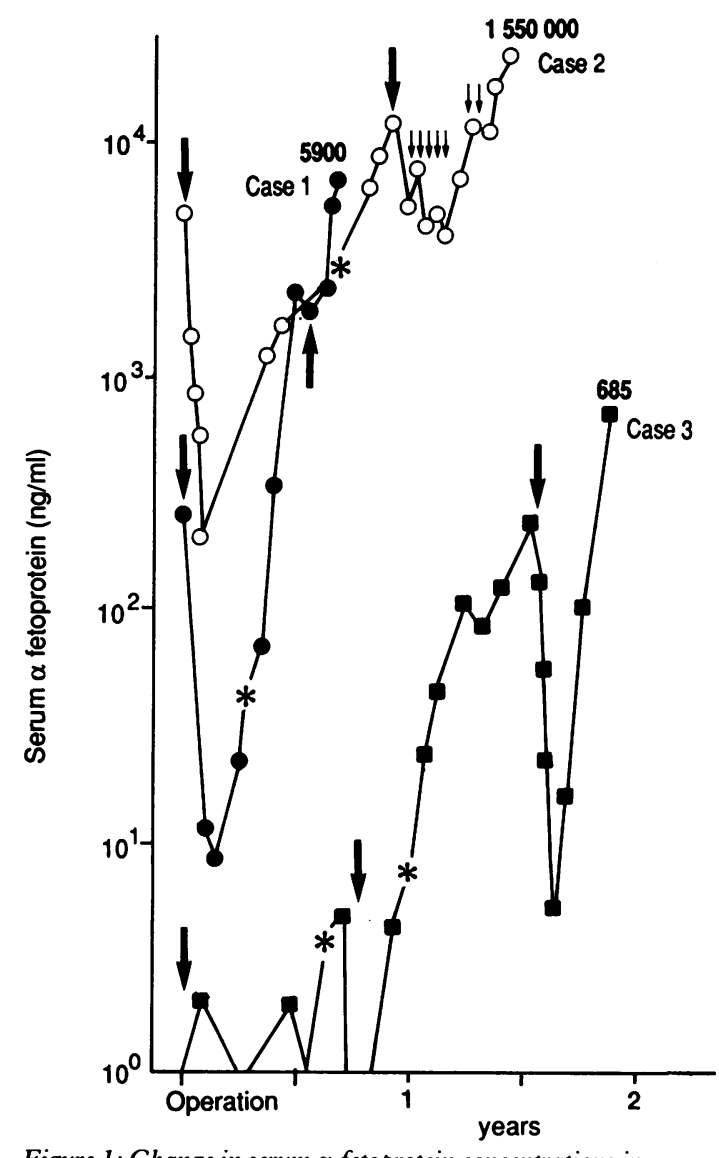

Figure 1: Change in serum $\alpha$ fetoprotein concentrations in cases 1-3. Large arrows=operation; ${ }^{\star}=$ recurrence; small arrows $=$ intra-arterial chemotherapy. 
during the operation and on the first postoperative day respectively. On discharge the serum $\alpha$ fetoprotein concentration decreased to 8 $\mathrm{ng} / \mathrm{ml}$ (Fig 1). Fifty four days after operation it had increased slightly. Abdominal ultrasonography showed a small hyperechoic lesion in the quadrate lobe of the liver. Three months later computed tomography showed two $12 \mathrm{~mm}$ tumours in the same portion. Only cannulation of the common hepatic artery could be carried out because disseminated tumours and tumour thrombus in the left portal vein were found with intra-operative ultrasound. Intra-arterial chemotherapy with $8 \mathrm{mg}$ mitomycin $\mathrm{C}$ and $40 \mathrm{mg}$ adriamycin was given once. But the tumour grew rapidly and she died 10 months after operation.

\section{Case 2}

A 59 year old man was admitted to the medical department because of a raised serum $\alpha$ fetoprotein concentration (up to $800 \mathrm{ng} / \mathrm{ml}$ ). He had had a history of liver dysfunction, probably due to hepatitis B virus infection but the serum $\alpha$ fetoprotein had not been high during that period. Abdominal ultrasonography, computed tomography, laparoscopy, angiography, and liver scintigraphy were performed with no conclusive findings. Liver functions were normal. Finally, a $2 \mathrm{~cm}$ irregular ulceration at the antrum was proved to be an $\alpha$ fetoprotein producing adenocarcinoma by an upper gastrointestinal series and endoscopic biopsy.

A partial gastrectomy and $R_{2}{ }^{15}$ lymph node dissection were performed. The liver was slightly fibrotic and chronic active hepatitis was recognised microscopically. Postoperatively, mitomycin C $20 \mathrm{mg}$ was given intravenously once and followed by oral tegafur $600 \mathrm{mg} /$ day. The $\alpha$ fetoprotein concentration decreased to $184 \mathrm{ng} / \mathrm{ml}$ at discharge (Fig 1) but rose to $1170 \mathrm{ng} / \mathrm{ml}$ four months later. Ultrasonography of the abdomen did not show recurrent or metastatic lesions. Nine months after operation a

TABLE I Details of patients

\begin{tabular}{|c|c|c|c|}
\hline & Case 1 & Case 2 & Case 3 \\
\hline $\begin{array}{l}\text { Age/sex } \\
\alpha \text { Fetoprotein before operation }(\mathrm{ng} / \mathrm{ml}) \\
\text { Carcinoembryonic antigen before }\end{array}$ & $\begin{array}{l}62 / F \\
146\end{array}$ & $\begin{array}{l}59 / \mathrm{M} \\
4800\end{array}$ & $\begin{array}{l}65 / M \\
<1\end{array}$ \\
\hline operation $(\mathrm{ng} / \mathrm{ml})$ & 3 & 3 & 0.6 \\
\hline Location & Body & Antrum & Antrum \\
\hline Tumour type & IIa & IIc & IIa \\
\hline Tumour size $(\mathrm{cm})$ & $4 \cdot 3 \times 2 \cdot 3$ & $1.6 \times 1 \cdot 2$ & $4.5 \times 3.3$ \\
\hline Depth & Submucosal & Submucosal & Submucosal \\
\hline Grade of lymph node metastasis $\dagger$ & 1 & 1 & \\
\hline Grade of lymph vessel invasiont & 2 & 3 & 3 \\
\hline Grade of venous invasion $\dagger$ & 2 & 0 & 3 \\
\hline $\begin{array}{l}\alpha \text { Fetoprotein staining of stomach } \\
\text { Liver metastasis }\end{array}$ & $\begin{array}{l}++ \\
+-\end{array}$ & $\begin{array}{l}+++ \\
+++\end{array}$ & $\begin{array}{l}+++ \\
+++\end{array}$ \\
\hline Pathology & $\begin{array}{l}\text { Poorly } \\
\text { differentiated }\end{array}$ & $\begin{array}{l}\text { Poorly } \\
\text { differentiated }\end{array}$ & Papillary \\
\hline $\begin{array}{l}\text { Interval to liver metastasis (days) } \\
\text { Survival (days) }\end{array}$ & $\begin{array}{l}54 \\
296\end{array}$ & $\begin{array}{l}335 \\
723\end{array}$ & $\begin{array}{l}228 \\
710\end{array}$ \\
\hline
\end{tabular}

$\star \mathrm{IIa}=$ protruding, $\mathrm{IIc}=$ depressed. + Classification of Japanese research society for gastric cancer. ${ }^{1+}$

TABLE II Diagnostic findings

\begin{tabular}{llll}
\hline Case & Angiography & Computed tomography & Ultrasonography \\
\hline 1 & $\begin{array}{l}\text { Hypervascular } \\
\text { +portal thrombus } \\
\text { Hypervascular } \\
\text { +right hepatic vein invasion }\end{array}$ & Low density & $\begin{array}{c}\text { Hyperechoic } \\
\text { +portal thrombus } \\
\text { Hyperechoic } \\
\text { +hypoechoic halo }\end{array}$ \\
3 & Low density & $\begin{array}{c}\text { Hyperechoic } \\
\text { +hypoechoic halo }\end{array}$ \\
\hline & Low density & & \\
\hline
\end{tabular}

$2 \mathrm{~cm}$ hyperechoic tumour with a hypoechoic halo was shown in the liver by ultrasound. Owing to multiple liver metastases and local recurrence at the root of the hepatoduodenal ligament, only cannulation of the common hepatic artery was performed. He then received intra-arterial chemotherapy with a total dose of cisplatin 330 $\mathrm{mg}$, mitomycin C $20 \mathrm{mg}$, adriamycin $114 \mathrm{mg}$, and 5-fluorouracil $4225 \mathrm{mg}$. The $\alpha$ fetoprotein concentration increased steadily, however, and lung metastasis subsequently occurred. When he died 24 months after operation the $\alpha$ fetoprotein concentration was $1550000 \mathrm{ng} / \mathrm{ml}$.

\section{Case 3}

A 65 year old man had complained of epigastric pain for one month. An upper gastrointestinal series and endoscopy of the stomach showed a well differentiated adenocarcinoma at the antrum. The serum $\alpha$ fetoprotein concentration was $1 \mathrm{ng} / \mathrm{ml}$.

Partial gastrectomy with $R_{2}^{15}$ lymph node dissection was performed. Postoperative adjuvant chemotherapy was given with oral tegafur $600 \mathrm{mg} /$ day. Six months later a low density area in the liver $4 \times 3 \mathrm{~cm}$ was shown by abdominal computed tomography while the serum $\alpha$ fetoprotein was $4 \mathrm{ng} / \mathrm{ml}$ (Fig 1 ). When hepatic resection was carried out, the $\alpha$ fetoprotein concentration remained unchanged but the carcinoembryonic antigen concentration rose from 1.8 to $3.3 \mathrm{ng} / \mathrm{ml}$. Three months later a low density area in the liver $2 \cdot 3 \mathrm{~cm}$ was found by computed tomography again. This time the $\alpha$ fetoprotein concentration had increased gradually, but the carcinoembryonic antigen concentration had not. The patient was followed up for five months to ascertain that it was a solitary tumour. Then an extended right lobectomy was performed. The $\alpha$ fetoprotein concentration fell from $224 \mathrm{ng} / \mathrm{ml}$ to normal one month later. But a low density area was discovered two months later. The serum $\alpha$ fetoprotein concentration had risen to $685 \mathrm{ng} / \mathrm{ml}$ when he died of a massive haemorrhage from a stomal ulcer.

\section{Discussion}

$\alpha$ Fetoprotein producing early gastric cancer has rarely been reported.$^{8}$ There are no published papers describing its clinicopathological features and prognosis. In our three cases two unusual characteristics are elucidated: poor prognosis and a high incidence of liver metastasis.

In our patients the incidence of $\alpha$ fetoprotein early gastric cancer among gastric cancer patients whose serum $\alpha$ fetoprotein concentration and $\alpha$ fetoprotein staining of a resected specimen had been investigated was $1 \cdot 85 \%(3 / 162)$. McIntire $e t$ $a l^{1}$ described a higher incidence (15\%) of $\alpha$ fetoprotein producing gastric cancer in cases from the Mayo Clinic and the National Institutes of Health than in Japan (about 5\%). Therefore, $\alpha$ fetoprotein early gastric cancer may also exist in Western counties. The histopathological and diagnostic features of the three cases are given in Tables I and II. The histology showed characteristic hepatoid foci ${ }^{16}$ in all patients. The findings of imaging resembled those of hepatocellular 
TABLE III Comparison between $\alpha$ fetoprotein producing and $\alpha$ fetoprotein negative early gastric cancer

\begin{tabular}{|c|c|c|c|}
\hline & & $\begin{array}{l}\alpha \text { Fetoprotein } \\
\text { producing }(n=3)\end{array}$ & $\begin{array}{l}\alpha \text { Fetoprotein } \\
\text { negative }(n=159)\end{array}$ \\
\hline \multicolumn{2}{|l|}{$\begin{array}{l}\text { Sex }(M: F) \\
\text { Age (years) }\end{array}$} & $\begin{array}{l}2: 1 \\
62\end{array}$ & $\begin{array}{l}103: 56 \\
60\end{array}$ \\
\hline \multicolumn{4}{|c|}{ Tumour type: } \\
\hline \multirow{2}{*}{\multicolumn{2}{|c|}{$\begin{array}{l}\text { Protruding (I, IIa) } \\
\text { Depressed (IIb, IIc, III) }\end{array}$}} & 2 & 25 \\
\hline & & & 94 \\
\hline \multicolumn{2}{|c|}{$\begin{array}{l}\text { Mixed } \\
\text { Denth. }\end{array}$} & 0 & 39 \\
\hline \multicolumn{4}{|l|}{ Depth: } \\
\hline \multicolumn{2}{|l|}{ Mucosa } & 0 & 75 \\
\hline Submucosa & & 3 & 84 \\
\hline \multicolumn{4}{|c|}{ Location of main tumour: } \\
\hline \multicolumn{2}{|c|}{ Cardia } & 0 & 17 \\
\hline \multirow{2}{*}{\multicolumn{2}{|c|}{$\begin{array}{l}\text { Body } \\
\text { Antrum }\end{array}$}} & 1 & 75 \\
\hline & & & 67 \\
\hline \multicolumn{2}{|c|}{ Lymph node metastasis } & $3 / 3^{\star \star}$ & $11 / 159^{\star \star}$ \\
\hline \multirow{2}{*}{\multicolumn{2}{|c|}{$\begin{array}{l}\text { Lymph vessel invasion: } \\
\text { None }\end{array}$}} & $3 / 3^{\star}$ & $40 / 150^{\star}$ \\
\hline & & 0 & 110 \\
\hline \multicolumn{2}{|l|}{ Mild } & 0 & 27 \\
\hline \multirow{2}{*}{\multicolumn{2}{|c|}{$\begin{array}{l}\text { Moderate } \\
\text { Severe }\end{array}$}} & 1 & 11 \\
\hline & & 2 & \\
\hline \multicolumn{2}{|l|}{ Venous invasion: } & $2 / 3^{\star}$ & $9 / 150^{\star}$ \\
\hline None & & 1 & 141 \\
\hline \multirow{2}{*}{$\begin{array}{l}\text { Mild } \\
\text { Moderate }\end{array}$} & & 0 & 9 \\
\hline & & 1 & 0 \\
\hline \multirow{2}{*}{\multicolumn{2}{|c|}{$\begin{array}{l}\text { Severe } \\
\text { Liver metastasis }\end{array}$}} & 1 & 0 \\
\hline \multirow{2}{*}{\multicolumn{2}{|c|}{$\begin{array}{l}\text { Liver metastasis } \\
\text { (secondary) }\end{array}$}} & & \\
\hline & & $3 / 3^{\star \star}$ & $3 / 159 \star \star$ \\
\hline \multicolumn{4}{|c|}{${ }^{\star} \mathrm{p}<0.05,{ }^{\star \star} \mathrm{p}<0.01$} \\
\hline \multicolumn{4}{|c|}{$\begin{array}{l}\text { TABLE IV Liver metastasis according to lymphatic (ly) and } \\
\text { venous }(v) \text { invasion of early gastric cancer }\end{array}$} \\
\hline & \multicolumn{3}{|c|}{ Liver metastasis } \\
\hline & \multicolumn{2}{|c|}{$\begin{array}{l}\alpha \text { Fetoprotein } \\
\text { producing }\end{array}$} & $\begin{array}{l}\alpha \text { Fetoprotein } \\
\text { negative }\end{array}$ \\
\hline & + & - & + \\
\hline $\begin{array}{l}\text { ly }(+) \text { and } v(+) \\
\text { ly }(+) \text { or v }(+)\end{array}$ & $\begin{array}{l}2 \\
3\end{array}$ & $\begin{array}{l}0 \\
0\end{array}$ & $\begin{array}{l}12 \\
44\end{array}$ \\
\hline
\end{tabular}

carcinoma, especially hypervascularity and invasion of portal and hepatic veins in angiography. With ultrasonography typical features of hepatocellular carcinoma - high echoic tumour accompanied by a hypoechoic rim (halo) - was also present in $\alpha$ fetoprotein early gastric cancer. Compared with $\alpha$ fetoprotein negative cancers (Table III), significant differences are recognised in the incidence of lymph node metastasis, lymph vessel invasion, venous invasion, and liver metastasis (Fisher's exact test).

Liver metastasis is well known in $\alpha$ fetoprotein producing advanced gastric cancer ${ }^{13-9}$ but has rarely been reported for $\alpha$ fetoprotein early gastric cancer. All our patients developed liver metastasis within two years. The incidence of liver metastasis for all early gastric cancers has usually been reported as less than $2 \%^{11-14}$ - the same incidence as we found. This appreciable difference may suggest the malignancy of $\alpha$ fetoprotein producing gastric cancer, whether or not the tumour was treated early. In Table IV a comparison is made to show that even with the same degree of lymphatic or venous invasion an $\alpha$ fetoprotein early gastric cancer has a stronger tendency to metastasize to the liver.

The five year survival rate for early gastric cancer in Japan ${ }^{10-14}$ is about $90 \%$. Figure 2 shows a similar result in our series using the KaplanMeier method. Patients with lymph node metastasis - all are disease free presently - are included. By contrast, patients with $\alpha$ fetoprotein early gastric cancer died of liver metastasis within two years despite radical surgery. The

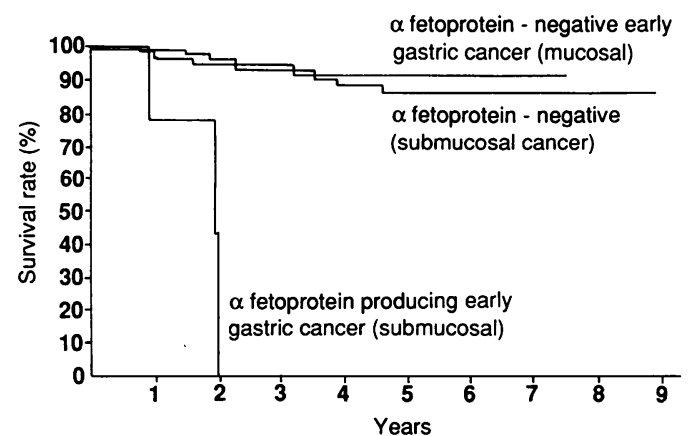

Figure 2: Survival curves of $\alpha$ fetoprotein producing and $\alpha$ fetoprotein negative early gastric cancers calculated by the Kaplan-Meier method.

two year survival rates were $94 \cdot 3 \%$ (mucosal), $96.5 \%$ (submucosal), and $0 \%(\mathrm{p}<0.05)$, and the five year survival rates were $91 \cdot 2 \%$ (mucosal), $86 \cdot 2 \%$ (submucosal), and $0 \%$ for $\alpha$ fetoprotein negative (mucosal, submucosal)and $\alpha$ fetoprotein producing early gastric cancers respectively $(\mathrm{p}<0.05)$

Early detection and curative resection for gastric and hepatic lesions do not seem sufficient for $\alpha$ fetoprotein early gastric cancers in our series. Postoperative adjuvant chemotherapy may be mandatory. Takahashi ${ }^{17}$ showed that a combination of mitomycin $\mathrm{C}$ and $\alpha$ fetoprotein antibody has an appreciable inhibitory effect on tumour growth. Our preliminary experiment with xenotransplanted nude mice also showed that mitomycin $\mathrm{C}$ may be an effective drug, particularly in cases with high $\alpha$ fetoprotein titres. Cases 1 and 2 had been given mitomycin $C$ once or twice postoperatively, but they did not show a good response. This was probably due to an insufficient dose or duration of treatment. The schedule of drugs and doses should be further investigated.

Case 3 was a latent case of $\alpha$ fetoprotein early gastric cancer. The serum $\alpha$ fetoprotein concentration rose only with the second live metastasis; however, all the resected specimens of the stomach and liver were positive for $\alpha$ fetoprotein staining. The incidence of a latent case seems rare. Among 68 patients with early gastric cancer with normal serum $\alpha$ fetoprotein concentrations Takahashi $e t a l^{4}$ failed to find a latent case with $\alpha$ fetoprotein staining of the resected stomach specimens. We are also unable to find other positive cases. In such latent cases $\alpha$ fetoprotein is probably secreted from the cancer tissue, but the amount of $\alpha$ fetoprotein production may be less and elimination from the blood is so rapid that it is undetectable.

1 McIntire KR, Waldman TA, Moertel CG, Go VLW. Serum $\alpha$ feto protein in patients with neoplasms of the gastrointestinal feto protein in patients with neop

2 Leader M, Jass JR. Increased $\alpha$-fetoprotein concentration in association with ileal adenocarcinoma complicating Crohn's disease. F Clin Pathol 1984; 37: 293-7.

3 Borreille J, Metayer P, Sauger F, et al. Existence d'alpha-foeto proteine au cours d'un cancer secondaire due foie d'origine gastrique. Presse Med 1970; 78: 1277-8.

4 Takahashi Y, Mai M, Ogino T, Ueda H, Sawaguchi K, Ueno $M$. Clinicopathological study of AFP producing gastric cancer. Significance of AFP in gastric cancer. Fournal of the fapanese Surgical Society 1987; 88: 696-700. (In Japanese with English abstract.)

5 Alpert E, Pinn VW, Isselbacher KJ. Alpha-fetoprotein in patient with a gastric carcinoma metastatic to the liver. $N$ EnglF Med 1971; 285: 1058-9.

5 Bierfeld JL, Scheiner MI, Schultz DR, Moral MD, Rogers AI. Alpha-fetoprotein and carcinoembryonic antigen in a case of gastric carcinoma metastatic to the liver. American foumal of Digestive Diseases 1973; 18: 517-20 
7 Ishikura H, Kirimoto K, Shamoto M, et al. Hepatoid adenocarcinoma of the stomach - an analysis of seven cases. Cancer 1986; 58: 119-26.

8 Tanaka M, Ohsawa J, Ami M, et al. A case of AFP-producing gastric cancer metastasized to the liver, resulting in an intrahepatic embolus of a tumor of the portal vein. Fournal of the Fapanese Society of Clinical Surgery 1988; 49: 81-7. (In Japanese with English abstract.)

9 Kato K, Akai S, Tobita Y, et al. $\alpha$-fetoprotein-positive cases in cancer except for hepatoma and malignant teratoma. Fap $\mathcal{f}$ Cancer Clin 1974; 20: 376-82. (In Japanese with English abstract.)

10 Kaneko E, Nakamura T, Umeda N, Fujino M, Niwa $H$. Outcome of gastric carcinoma detected by gastric mass survey in Japan. Gut 1977; 18: 626

11 Koga S, Kaibara N, Tamura H, Nishidoi H, Kimura O. Cause of late postoperative death in patients with early gastric cancer with special reference to recurrence and the incidence of metachronous primary cancer in other organs. Surgery 1984; 96: 511-6.
12 Habu H, Takeshita $K$, Sunagawa $M$, Endo $M$. Prognostic factors of early gastric cancer - results of long-term followup and analysis of recurrent cases. F p $\mathcal{F}$ Surg 1987; 17: 24855

13 Abe S, Ogawa Y, Nagasue N, et al. Early gastric cancer: results in a general hospital in Japan. World 7 Surg $1984 ; 8: 308-14$ 4 Yasuna $\mathrm{O}$, Hayashi S. Factors influencing the postoperative course of 113 patients with early gastric cancer. $\mathcal{F} p n \mathcal{F}$ Clin

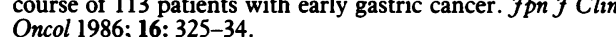

15 Japanese Research Society for Gastric Cancer. The general rules for the gastric cancer study in surgery and pathology. fpn $\mathcal{F}$ Surg 1981; 11: 127-45.

16 Ishikura H, Fukasawa Y, Ogasawara K, Natori T, Tsukada Y, Aizawa M. An AFP-producing gastric carcinoma with features of hepatoid differentiation: a case report. Cancer 1985; 56: 840-8.

17 Takahashi Y. Characterization of human AFP producing stomach cancer xenotransplanted in nude mice and effect of a conjugate of MMC and antibody to human AFP on this tumour. Gastroenterol fpn 1985; 81: 18-27. 